\title{
Recovering Scrap Anode Copper Using Reactive Electrodialysis
}

\author{
Gerardo Cifuentes, José Hernández, Nicolás Guajardo \\ Department of Metallurgical Engineering, Universidad de Santiago de Chile, Santiago, Chile \\ Email: gerardo.cifuentes@usach.cl
}

Received 23 August 2014; revised 8 October 2014; accepted 24 October 2014

Copyright (C) 2014 by authors and Scientific Research Publishing Inc.

This work is licensed under the Creative Commons Attribution International License (CC BY). http://creativecommons.org/licenses/by/4.0/

(c) (i) Open Access

\begin{abstract}
Despite functioning without major operational problems-copper electro-refining does not allow complete use of copper anodes, peaking at $85 \%$ of the copper anode in weight. Consequently, the remaining $15 \%$ of scrap copper must be recirculated into the copper smelting. The use of reactive electrodyalysis is a system capable of continuously electro-refining scrap, by using a stainless steel basket and a cationic exchanging membrane in order to increase production of copper cathodes at the same percentage; it currently today returns to the copper smelter. In terms of specific energy consumption, this process would use between 3 and 4 times the value of normal electro-refining.
\end{abstract}

\section{Keywords}

Electro-Refining, Copper Scrap, Reactive Electro-Dialysis

\section{Introduction}

Copper electro-refining is the electrochemical dissolution of an anode of the same material of the smelting process, which contains $99.5 \%$ copper weight, and then is deposited onto a stainless steel sheet with 99.99\% pure copper [1] [2]. The fundamental process is illustrated in Figure 1.

In Figure 1 it is noted that the electro-refining requires a steady electrical supply, a positive electrode (anode), a negative electrode (cathode), and a conducting electrolyte to transport the ions in order to close the electrical circuit.

To decrease the electricity consumption of the system, the electrolyte has a high concentration of copper sulphate and sulfuric acid. The ions of both types in the solution increase the electrolytes' conductivity.

As observed in Figure 2, the remaining scrap copper anodes must be removed from the electro-refining cell without being completely dissolved for 2 reasons: 


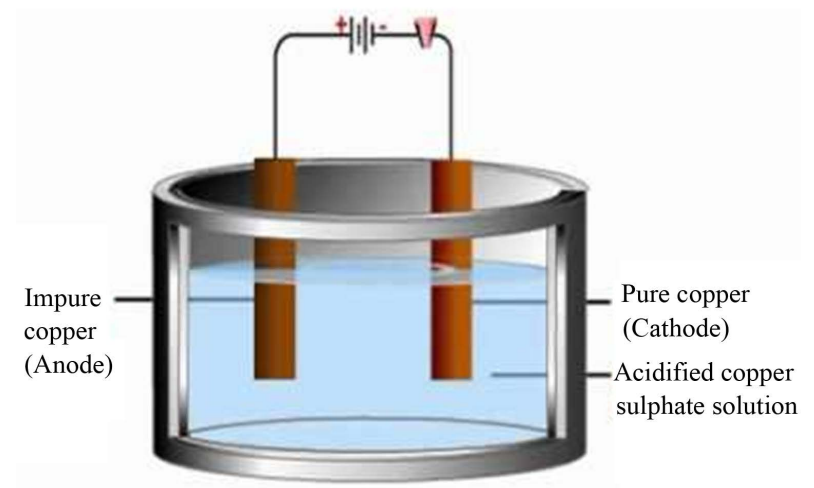

Figure 1. Copper electro-refining.

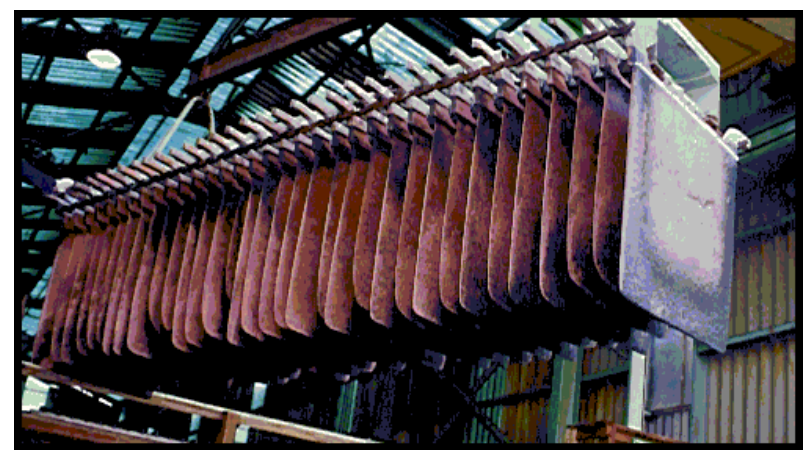

Figure 2. Scrap copper anode returned to the smelting process.

In the first place, the anode section that is dissolved is only the one immersed in the electrolyte. The anode cannot be completely immersed due to the electrical connection with the power source. If the latter is immersed, it would dissolve along with the anode and the process would stop.

The second reason preventing the scrap from dissolving is the quality of the copper deposit: if the cathode is not morphologically regular, its mechanical properties (hardness, resistance, etc.) would be low and therefore it would be unfit to continue the following processes. To obtain a high-quality cathode, the anode's surface must be as homogeneous as possible in order not to produce preferential deposits on the cathode. Because the scrap copper anode is not morphologically regular, the cathode resulting of this process would have a bad quality surface.

Consequently, the result of an eventual electro-refining using scrap would result in a cathode unfit for the following stages. In practical terms, this problem represents a percentage of copper which cannot leave the circuit, that is, a circulating charge within the process.

In overall, despite functioning without major operational problems, the copper electrorefining process in actuality does not allow complete use of copper anodes, only peaking at $85 \%$ of the copper anode in weight. Consequently, the remaining $15 \%$ of scrap copper must be recirculated into the copper smelting. The use of reactive electrodyalysis is a system capable of continuously electrorefining scrap, by using a stainless steel basket and a cation exchanging membrane in order to increase production of copper cathodes at the same percentage; it currently today returns to the copper smelter.

If a system capable of producing copper cathodes from scrap was implemented, the electro-refining plants productive capacity would increase the same $15 \%$ of the copper which at present re-circulates in the smelting process.

In other side, electroplating [3]-[5] objectives are coating a metal piece by dissolving one metal followed by the electro-deposition on the surface of the piece to coating. It is common practice to use stainless steel baskets as supporting electrodes to provide electrical connection to additional metal parts to the baskets system because, as in the case of scrap copper anodes, morphologically irregular metals are usually used input. Using a basket results in high-quality surface, regardless of the morphology of the metal put inside. Therefore, this electrode support shall be used to dissolve scrap pieces copper anode. 
Additionally, electro-dialysis [6]-[11] is the procedure of purifying or concentrating solutions by applying a potential difference and separating the compartments by an ion exchange membrane (see Figure 3). These membranes have the quality of being selective to the transfer of ions through them: anionic and cationic. This system in this study uses a cationic exchange membrane for copper ion transfer from the anode to the cathode. The reason for this is the constant generation of the anode slime inside the stainless steel basket. The accumulation of slime decreases the electrical contact inside the anode, gradually increasing the potential system consumption to the point of corroding the stainless steel and stopping the process. In this case, the slime shall be removed by the localized electrolyte flow inside and removed from the system using a sediment tank. The function of the cationic membrane is to prevent the anode slime from contaminating the catholyte and consequently the resulting copper cathode after being removed from the basket.

The authors [12] [13] have worked with similar system but without membrane; these studies showed that the problematic parameters were: the anodic pasivation, the accumulation of anodic slimes inside the cell, the impossibility of high stirring of the electrolyte and others.

To solve all of these problematics of operation above-mentioned, it proposes the reactive electrodialysis as a new alternative that this work shows.

\section{Experiment Development}

To perform the tests, the first step is to treat the surface pieces $\left(1 \times 1 \mathrm{~cm}^{2}\right)$ of scrap copper to remove any product adhering to the surface. For this, it is immersed in a $10 \%$ nitric acid solution which is capable of stripping the entire working surface (see Figure 4).

The cell used in this work (Figure 5) is made up of two compartments separated by a cationic IONAC MC-3480 membrane (Figure 6)

The cathode (Figure 7) of stainless steel 316L $\left(5 \times 3 \mathrm{~cm}^{2}\right)$ is located in the left compartment of the cell (see Figure 5), and the basket with scrap copper (Figure 8) to the right.

The following diagram (Figure 9) represents the method of working used in this study:

The working conditions tested were $25^{\circ} \mathrm{C}, 30^{\circ} \mathrm{C}, 35^{\circ} \mathrm{C}$ and $40^{\circ} \mathrm{C}$ of temperature and cathode current densities of 166.6; 200; 233 and $266.6 \mathrm{~A} / \mathrm{m}^{2}$, equivalent to a current of 0.25 ; $0.30 ; 0.35$ and $0.40 \mathrm{~A}$. The used anolyte and catholyte had a copper concentration of $30 \mathrm{~g} / \mathrm{L}$ and $150 \mathrm{~g} / \mathrm{L}$ of sulfuric acid.

Electrolytes were re-circulated in both compartments using a $1.8 \mathrm{~mL} / \mathrm{s}$ flow. However, in the case of the anodic half cell (Figure 9), a hose was placed in the basket to apply localized injection of electrolyte to constantly stir the anode slime formed inside and remove it from the circuit using the sediment tank.

\section{Results}

First of all, the importance of the existing flux inside the basket and the temperature of the system must be evaluated. For this, voltammetry curves were drawn for different working conditions. The results are shown in Figure 10.

Figure 10 shows the importance of stirring and temperature: the importance of the former is seen compared to the voltammetry at $25^{\circ} \mathrm{C}$ with (red curve) and without stirring (black curve). It is deduced that, if the system is not

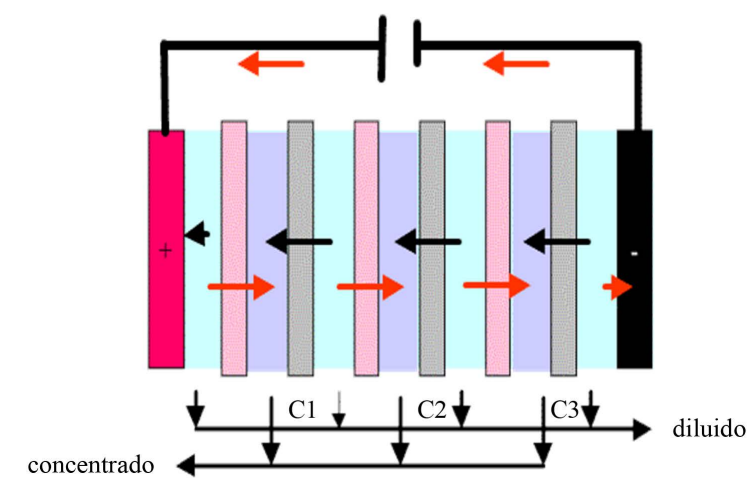

Figure 3. General scheme of the reactive electro-dialysis. 


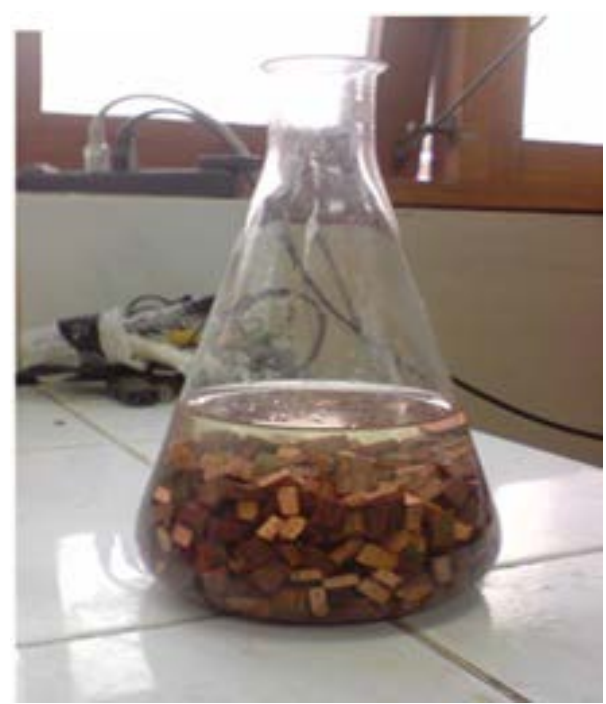

Figure 4. Scrap copper anode $1 \times 1 \mathrm{~cm}^{2}$ in surface and treated with $\mathrm{HNO}_{3}$ at $10 \%$.

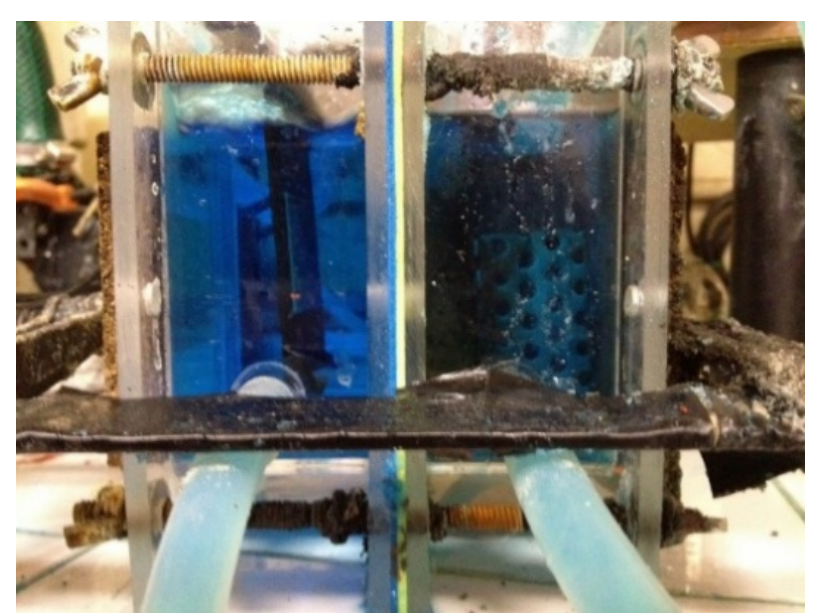

Figure 5. Used work cell. Left: catholyte; Right: anolyte.

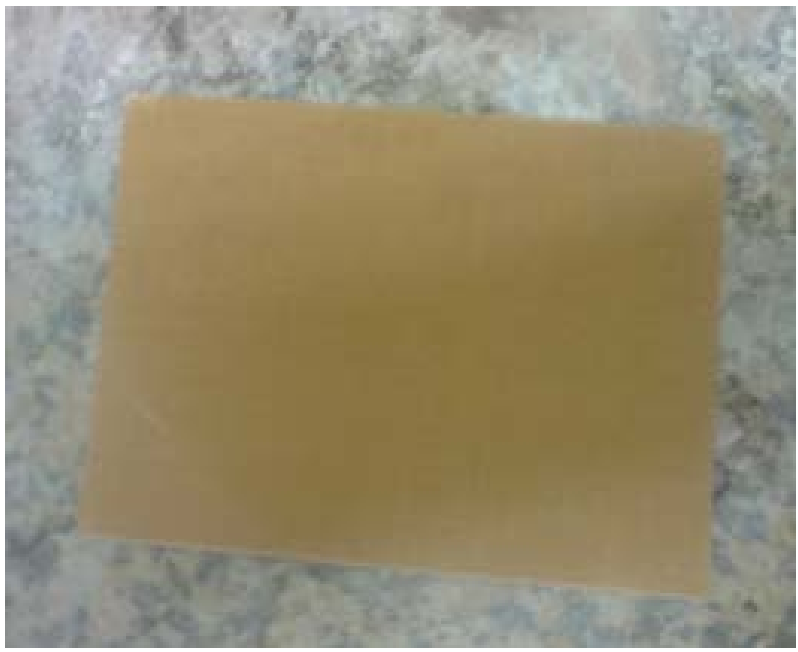

Figure 6. Cationic exchange membrane IONAC MC-3480. 


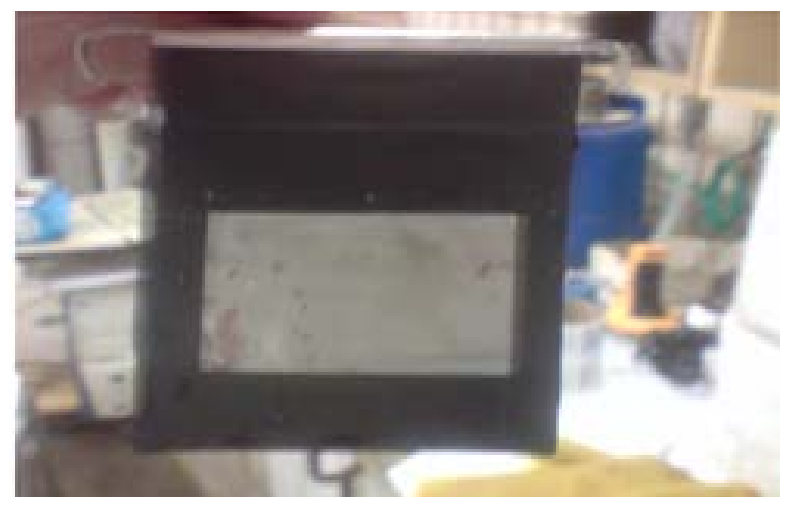

Figure 7. Stainless steel cathode of $5 \times 3 \mathrm{~cm}^{2}$.

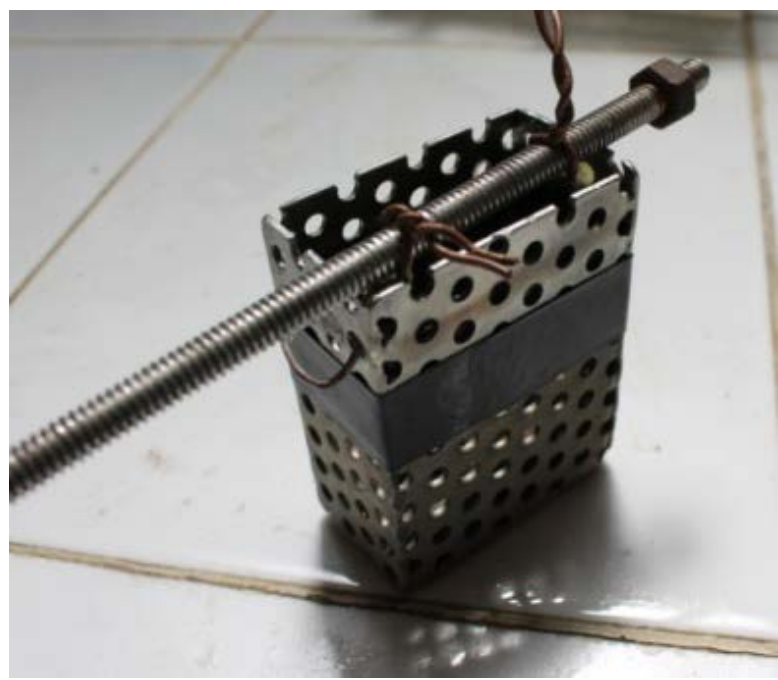

Figure 8. Stainless steel basket.

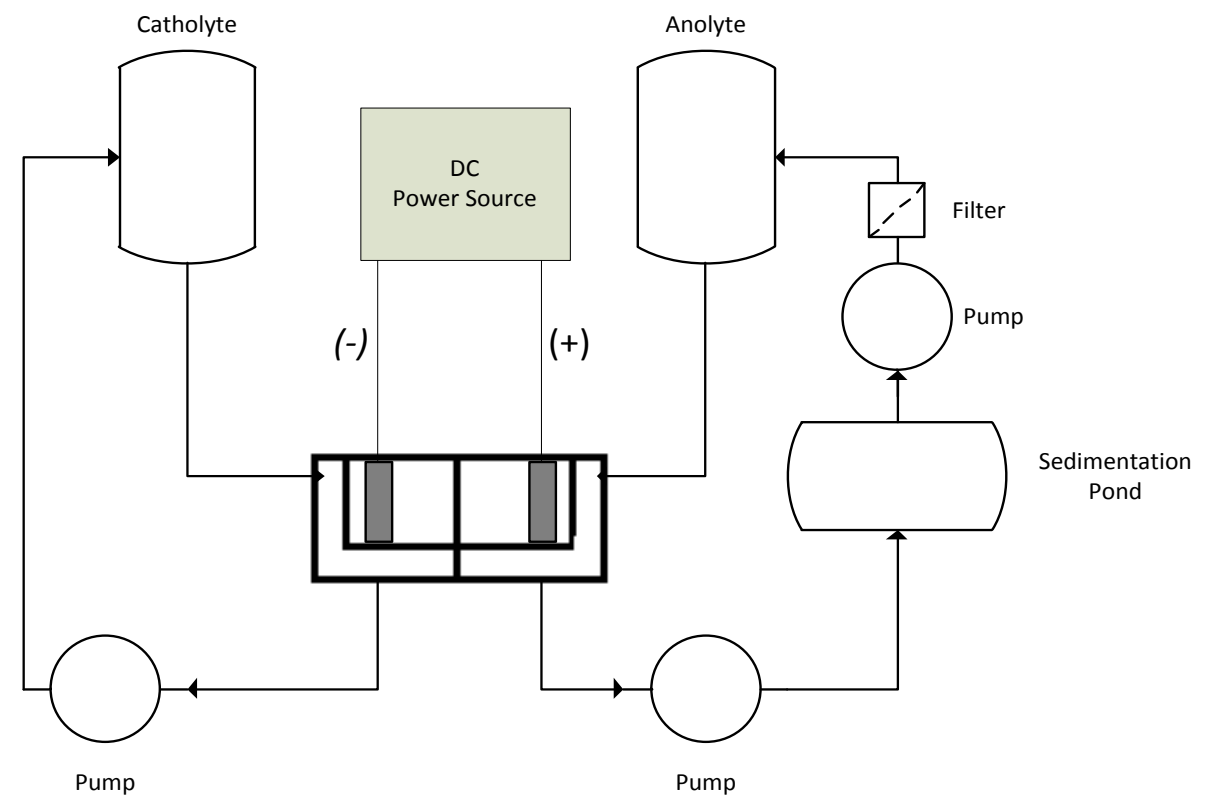

Figure 9. Diagram of the system used. 


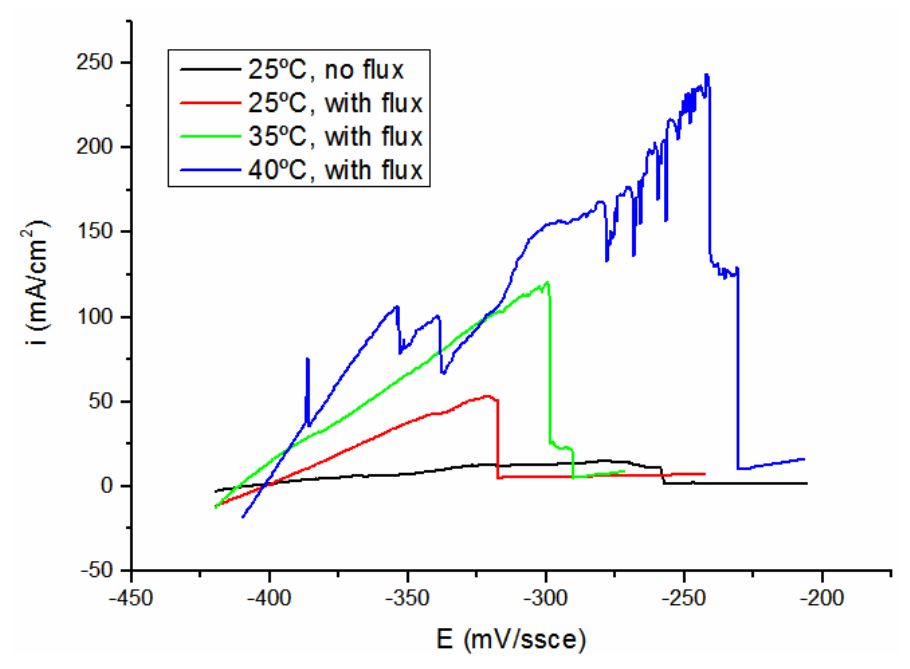

Figure 10. Voltammetry drawn for the system in different working conditions.

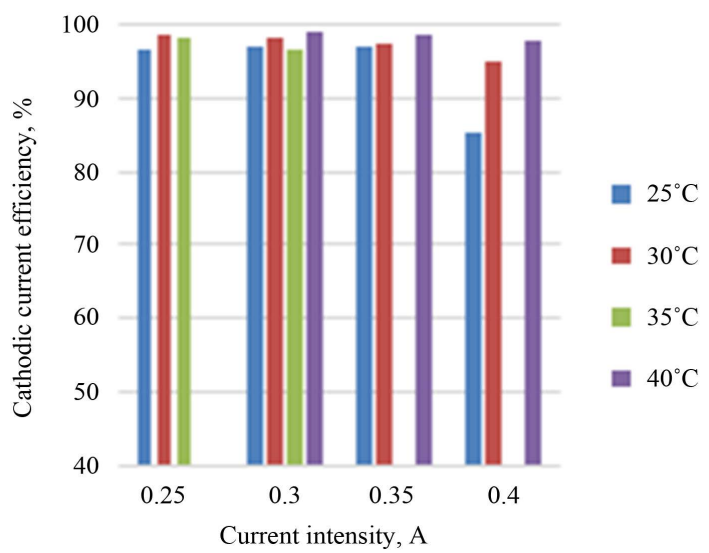

Figure 11. Efficiency of cathodic current v/s current intensity.

stirred, the scrap copper inside the basket would become passive due to the accumulation of copper ions in the copper/solution interface, in addition to the accumulation of anode slime which obstructs the electrical contact between the stainless steel and the copper.

In the same way, by increasing the temperature to $35^{\circ} \mathrm{C}$ and $40^{\circ} \mathrm{C}$ (green and blue curves), Figure 10 shows the effect on the electrode, that is, increasing the passivation critical current in all the cases. This means that the higher the temperature, the harder it is for the scrap copper to become passive inside the basket. The reason for this phenomenon is due to the increase of the solubility in the system. As the latter increases, more copper ions are capable of maintaining the solution in the system before the first copper sulphate precipitates.

Table 1 presents a summary of the working conditions in which the tests electro-refining tests of scrap were conducted using reactive electro-dialysis.

Graphing the data presented in Table 1, we can analyze the influence of the intensity of the current and the temperature on the results obtained in the studied system. This is shown in Figure 11.

Figure 11 shows that as temperature rises, the current efficiency of the process increases, and the highest effect is observed for current intensity of $0.4 \mathrm{~A}$. This is explained using the schematic Evans diagram (Figure 12), where it is observed that as the temperature rises, anode and cathode over potential $\left(\eta_{a} y \eta_{c}\right)$ decreases due to the increase in the kinetics of the process. As a consequence, the deposition of copper on the cathode is more selective, because the occurrence of parasite reactions is the system are obstructed, for example, such as the evolution of hydrogen in the cathode.

Figure 12 and Figure 13 show the synergistic effect of temperature and current density on the energy consumption of the system: at low levels of current intensity, the temperature rise is not seen as a relevant condition; 
Table 1. Scrap electro-refining test results.

\begin{tabular}{ccccc}
\hline No & Current intensity (A) & Temperature $\left({ }^{\circ} \mathrm{C}\right)$ & Current efficiency (\%) & Specific consumption $(\mathrm{Wh} / \mathrm{Kg} \cdot \mathrm{Cu})$ \\
\hline 1 & 0.25 & 26 & 96.53 & 619 \\
2 & 0.3 & 27 & 97.01 & 757 \\
3 & 0.35 & 26.1 & 97.1 & 961 \\
4 & 0.4 & 25 & 85.28 & 1397 \\
5 & 0.25 & 30 & 98.64 & 544 \\
6 & 0.3 & 30 & 98.32 & 734 \\
7 & 0.35 & 30 & 97.28 & 725 \\
8 & 0.4 & 30 & 97.94 & 801 \\
9 & 0.25 & 35 & 98.34 & 569 \\
10 & 0.3 & 35 & 98.72 & 658 \\
11 & 0.3 & 40 & 99.02 & 674 \\
12 & 0.35 & 40 & 98.46 & 703 \\
13 & 0.4 & 40 & 97.91 & 744 \\
\hline
\end{tabular}

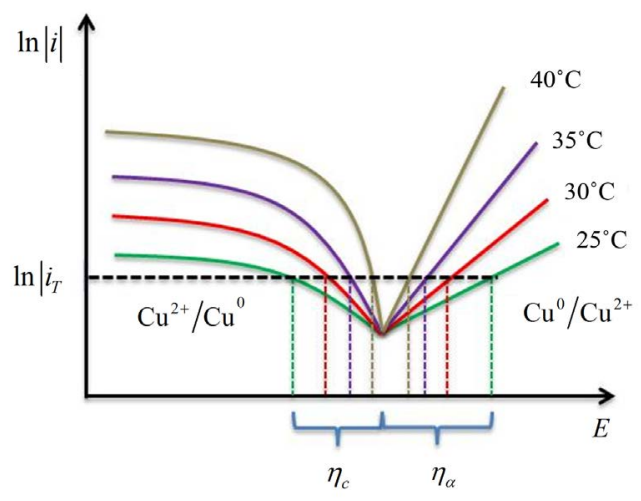

Figure 12. Evans diagram for the main electro-refining reactions.

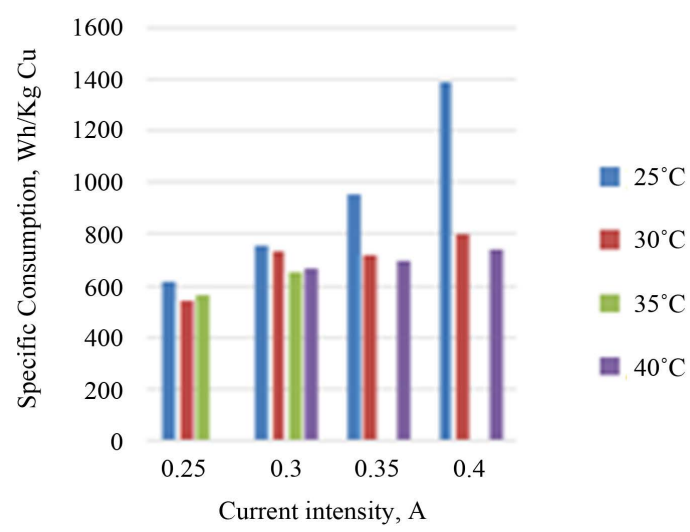

Figure 13. Specific energy consumption v/s current intensity.

besides, best deposit quality and copper recovery are also obtained. However, this directly affects the production rate, which is fundamental for the economic assessment of the process. The increase in temperature enables an 
increase in current density without affecting the current efficiency and specific energy consumption. This effect will be more pronounces at a higher current intensity.

To compare the specific energy consumption in this particular system with electro-refining used at an industrial level [14], this parameter for different conditions of current densities and temperatures was plotted. The normal electro-refining process has a specific consumption of $200 \mathrm{Wh} / \mathrm{Kg} \cdot \mathrm{Cu}$. Figure 13 shows that the results for this system vary between 600 and $800 \mathrm{Wh} / \mathrm{Kg} \cdot \mathrm{Cu}$, that is, in terms of energy, this process would cost between 3 and 4 times the value of normal electro-refining. However, its implementation would enable the production of copper cathodes of $15 \%$ of the total weight of the copper anode which is returned to the conversion process, while increasing the smelting production capacity by not treating the circulating charge of anode scrap copper.

\section{Conclusions}

From this work it can be concluded that it is possible to electro-refine scrap copper anode under working conditions similar to those used industrially.

Temperature also plays a key role in the proposed system because it is the parameter which enables improvement of all operational parameters such as critical current passivation, current efficiency and specific energy consumption.

\section{Acknowledgements}

Support of this work by DICYT of the Universidad de Santiago de Chile is gratefully acknowledged.

\section{References}

[1] Cifuentes, G., Vargas, C. and Simpson, J. (2009) Analysis of the Main Variables That Influence the Cathodic Rejection during Copper Electrorefining (Análisis de las principales variables que influyen en el rechazo catódico durante el electrorrefino del cobre). Revista de Metalurgia, 45, 228-236. http://dx.doi.org/10.3989/revmetalm.0729

[2] Davenport, G., King, M., Schlesinger, M. and Biswas, A.K. (2002) Extractive Metallurgy of Copper. 3rd Edition, Elsevier, Oxford.

[3] Hartinger, L. (1990) Handbook of Effluent Treatment and Recycling for the Metal Finishing Industry. 2nd Edition, Carl Hanser, Munich.

[4] Di Bari, G. (2000) Nickel Plating. Metal Finishing, 98, 270-288. http://dx.doi.org/10.1016/S0026-0576(00)80334-7

[5] Chena, S.-S., Lib, C.-W., Hsua, H.-D., Leeb, P.-C., Changa, Y.-M. and Yang, C.-H. (2009) Concentration and Purification of Chromate from Electroplating Wastewater by Two-Stage Electrodialysis Processes. Journal of Hazardous Materials, 161, 1075-1080. http://dx.doi.org/10.1016/j.jhazmat.2008.04.106

[6] Llorens, J. (1992) Membranes Technology (Tecnología de Membranas). Class Notes, University of Barcelona, Barcelona.

[7] Schirg, P.G. (2010) Introduction to Theory and Practice in Technical Membranes (Introducción a la teoría y práctica de la Técnica de Membranas). PS Prozesstechnike GMBH. www.membran.com

[8] Koter, S. and Warszawski, A. (2000) Electromembrane Processes in Environment Protection. Polish Journal of Environmental Studies, 9, 45-56.

[9] Xu, T.W. (2005) Ion Exchange Membranes: State of Their Development and Perspective. Journal of Membrane Science, 263, 1-29. http://dx.doi.org/10.1016/j.memsci.2005.05.002

[10] Baker, R.W. (2004) Chapter 10: Ionic Exchange Membranes in Electro-Dialysis Processes. In: Membrane Technology and Applications, 2nd Edition, John Wiley Sons, Ltd., Hoboken. http://dx.doi.org/10.1002/0470020393.ch10

[11] Bernardes, A.M., Siqueira, M.A. and Zoppas, J. (2013) Electrodialysis and Water Reuse: Novel Approaches—Topics in Mining, Metallurgy and Materials Engineering. Springer, Berlin-Heidelberg.

[12] Herrera, C. (2003) Electrolytic Refining of Particulate Anodicshot (Refinación electrolítica de scrap anódico granallado). Titulation Work, Metallurgical Department, University of Santiago of Chile, Santiago.

[13] Urra, C. (2003) Electrolytic Refining of Particulate Anodic Scrap (Refinación electrolítica de scrap anódico particulado). Titulation Work, Metallurgical Department, University of Santiago of Chile, Santiago.

[14] Cifuentes, G., Simpson, J., Lobos, F., Briones, L. and Morales, A. (2009) Copper Electrowinning Based on Ractive Electrodialysis. Journal of the Chilean Chemical Society, 54, 334-338. http://dx.doi.org/10.4067/S0717-97072009000400002 
Scientific Research Publishing (SCIRP) is one of the largest Open Access journal publishers. It is currently publishing more than 200 open access, online, peer-reviewed journals covering a wide range of academic disciplines. SCIRP serves the worldwide academic communities and contributes to the progress and application of science with its publication.

Other selected journals from SCIRP are listed as below. Submit your manuscript to us via either submit@scirp.org or Online Submission Portal.
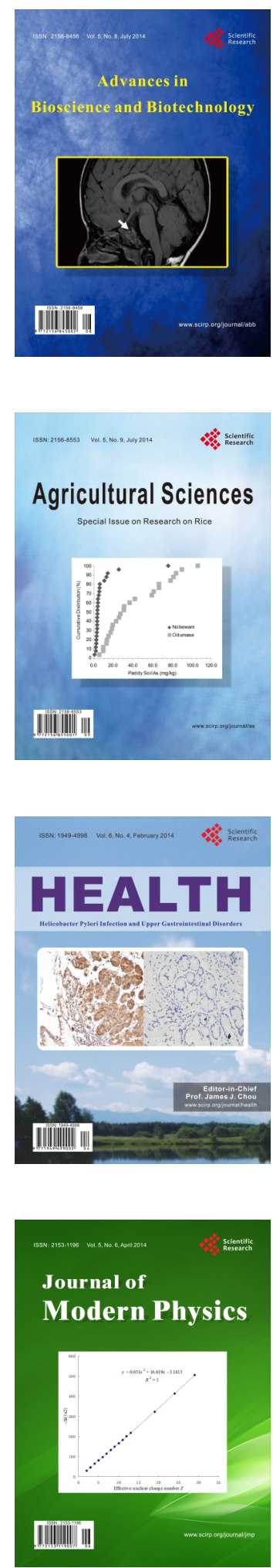
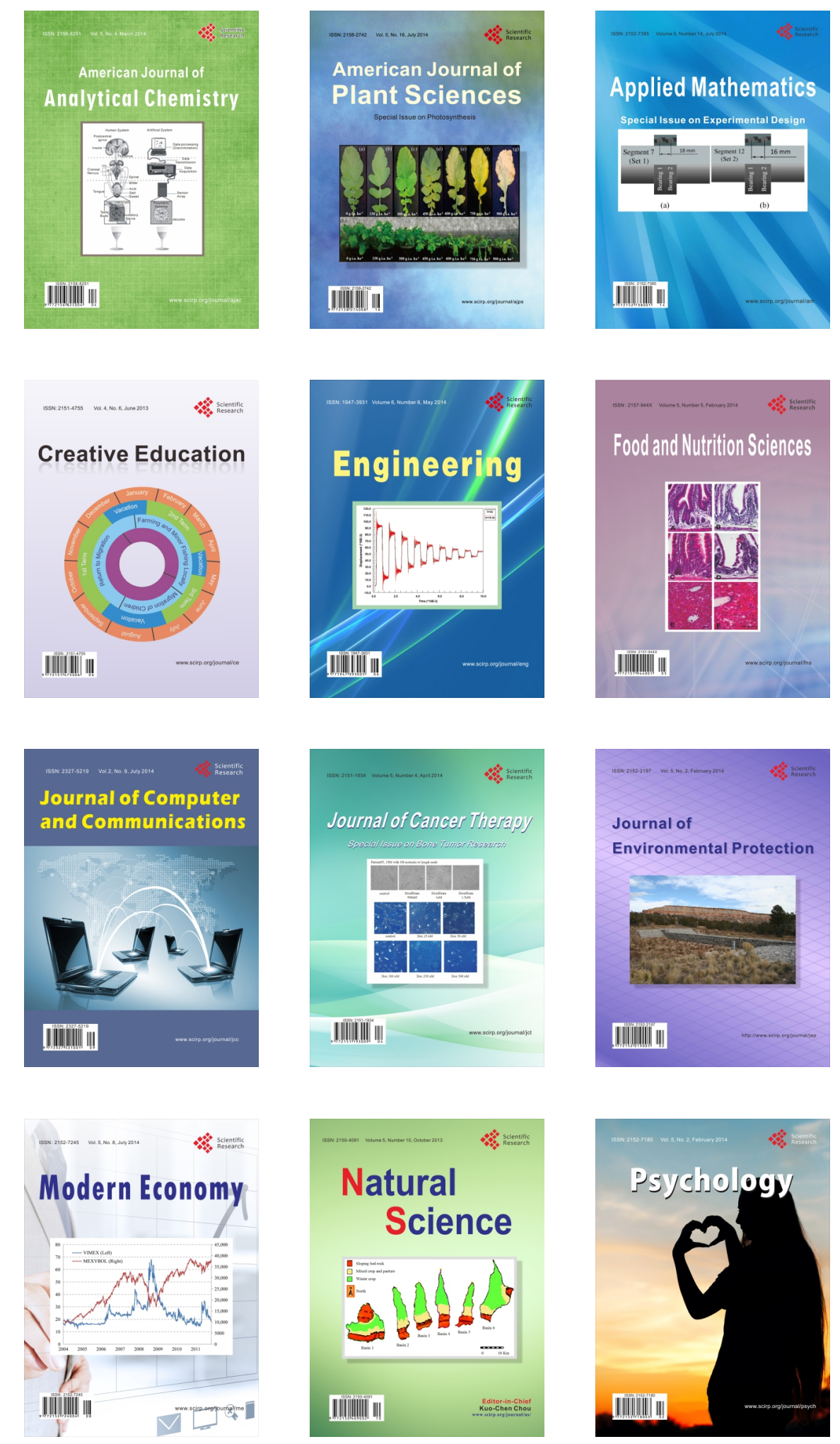